\title{
Inferring Environmental Change in Estuaries from Plant Macrofossils
}

\author{
John Tibby ${ }^{1}$ and Carl D. Sayer ${ }^{2}$ \\ ${ }^{\mathbf{1}}$ Department of Geography, Environment and Population \\ University of Adelaide \\ Adelaide, SA, 5005 \\ john.tibby@adelaide.edu.au \\ ${ }^{2}$ Environmental Change Research Centre, Department of Geography \\ University College London, Gower Street, London, WC1E 6BT, UK \\ c.sayer@ucl.ac.uk
}

\begin{abstract}
Authors to add (150-250 words)
Aquatic plants are critical components of estuarine ecosystems supporting biodiversity and a range of ecosystem services such as sediment stabilisation and denitrification. However, estuarine plants, similar to their freshwater counterparts, are in decline and under threat. The examination of remains of aquatic plants in sediment records can document the fate of the plants themselves, along with numerous natural and anthropogenic changes in estuaries, including those associated with relative sea level change, pollution and habitat degradation. In comparison with other proxies, the use of macrofossils in estuaries is in its relative infancy. However, many approaches to the examination of plant macrofossils can be utilised from the freshwater domain where a number of advances have been made, particularly in the past decade.
\end{abstract}

Keywords: charophytes, sea level, abstraction, river regulation, benchmark, baseline

"It was a good tree by the sea-loch, with many cones and much sunshine" Robert Jenkins (1980), The Cone Gatherers.

\section{Introduction}

${ }^{1} \mathrm{~J}$. Tibby (corresponding author) ${ }^{2}$ C.D. Sayer 
Estuarine ecosystems are transitional between freshwater and fully marine water bodies. They encompass a variety of often inter-connected environments: salt-tolerant forest, saltmarshes and open water, varying in terms of tidal activity and salinity, and include river mouths, fjords, coastal lagoons and coastal lakes. This continuum of habitats hosts a variety of aquatic plants ranging from large trees which require only limited contact with water at a specific stage in their life style (e.g. Casuarina and Melaleuca species in Oceania; Adam 2012) through mangroves (particularly in the tropics and sub-tropics) and saltmarsh plants (temperate zone and high latitudes) to submerged angiosperms, and macro and microalgae with an obligate requirement for water. This review focuses on coastal plants that leave macro-remains in sediments: plant remains that can be seen with the naked eye, in contrast to pollen and microspores, but which usually require microscope identification (sensu Birks 2001). Thus, this chapter excludes microalgae, which are covered elsewhere (Taffs et al. and Ellegaard et al., this volume). Furthermore, due the nature of preservation of plant remains, which is generally best under anoxic conditions close to the site of production, this chapter is largely focused on plants which are either submerged in, or occur at the margins of, coastal water bodies.

Aquatic plants play a fundamental role in estuaries and coastal lakes. The structure they afford provides refugia, feeding and ambushing habitat for a myriad of life-forms from bacteria to birds and fishes. Furthermore, seagrass meadows (and associated epiphytes) and saltmarshes are major sources of primary productivity (Borowitzka et al. 2006; Mitsch and Gosselink, 2007) and, as well as mediating species interactions, form a key component of estuarine food webs. Organic matter derived from seagrasses strongly influences denitrification, a critical process in reducing the effects of coastal eutrophication (Eyre et al. 2013). The roots and rhizomes of aquatic plants bind sediment, preventing its re-suspension into the water column, influencing sediment transport and water turbidity. Thus, estuarine vegetation is fundamentally important to the overall structure and function of estuaries, with strong correlations between the abundance and diversity of plants and ecosystem health (Orth et al. 2006; Montefalcone 2009). As an example, although there are limited studies, of the 115 marine species that live in seagrasses assessed using the International Union for the Conservation of Nature (IUCN) Red List criteria (IUCN, 2010), 31 (27\%) are in threatened categories (Short et al. 2011). These include invertebrates, fishes, sea turtles, and iconic marine mammals such as manatee and dugong (Short et al. 2011).

Many estuarine plants and plant-dominated habitats are in steep decline, rendering them of considerable importance from a nature conservation perspective. Short et al. (2011) show that $24 \%$ of seagrass species ( 15 of 72 species) are threatened or near threatened using IUCN criteria. Saltmarshes and their characteristic plants are in decline on a global scale, due to a combination of factors, not least urbanisation, hydrological manipulation, conversion for aquaculture, eutrophication and the negative influences of invasive species (Bromberg Gedan et al. 2009). In addition, mangrove swamps are rapidly disappearing due to widespread deforestation and climate change (Alongi 2008). Several species of charophytes (Chlorophyta: Characeae) are confined to a small number of coastal lakes and lagoons where they are becoming increasingly rare and, in some cases, threatened with extinction (Blindow, 2000; Martin et al. 2002). In turn, charophyte beds are often of crucial importance to invertebrates and fishes in coastal waters (Torn et al. 2010), so the knock-on effects of losing them are substantial. Clearly estuarine aquatic plants are 
highly sensitive to human impacts and, as such, can be seen to act as 'bellwethers' for environmental change (Short et al. 2011).

Massive and continuing reductions in the coverage of estuarine aquatic plants have been documented across the globe (Waycott et al. 2009; Bromberg Gedan 2009). However, much of this research has been undertaken in the $21^{\text {st }}$ century, with the vast majority in the last 50 years and largely focussed on regions with "developed" economies (Waycott et al. 2009). As such, in the absence of palaeoecological records, human understanding of fundamental environmental change in estuaries is 'blind' to numerous significant alterations that occurred before monitoring commenced or in the many parts of the world where monitoring is limited, or indeed non-existent (e.g. Birks et al. 2001b; Waycott et al. 2009). Major threats to estuarine plants include sealevel rise, increased temperature, hydrological change, sedimentation and nutrientenrichment mediated through excess algal growth on the plants themselves or in the water column (see Orth et al. 2006 and references therein). Many of these threats arise because estuarine plants often have a greater requirement for light than their terrestrial counterparts (Orth et al. 2006). Importantly, as well as reconstructing past plant communities, palaeoenvironmental studies are able to infer changes in these stressors through dating changes in sedimentation rates and habitat structure (Andersen, this volume); and via inferences about changing water quality (Weckström et al., this volume).

This chapter outlines research that has used plant macro-remains to infer environmental change in estuaries, with a particular focus on the reconstruction of sea-level change and human impacts. Plant macrofossils, or 'macro-remains', consist of reproductive structures such as seeds, fruits, turions and spores, and various vegetative fragments including leaves (frequently leaf tips), spines and roots. In freshwater lakes, where macrofossil analysis is well established, macrofossil analysis has been widely used to reconstruct aquatic vegetation histories and, in turn, to determine long-term lake ecosystem responses to eutrophication (Davidson et al. 2005; Madgwick et al. 2011), lake-level fluctuations linked to climate variation (Diggerfeldt, 1986; Dieffenbacher-Krall and Nurse, 2005), shallowing (Bradshaw et al. 2005) and changing plant biogeography (Bennike et al. 2001). A reasonable body of plant-based, palaeoecological research has also been undertaken in estuarine settings, including coastal lakes, lagoons, saltmarshes and river mouths. The case studies discussed below are organised thematically, rather than by habitat type, and are divided into relative sea-level change, human impacts, informing nature conservation, methodological considerations and the future of the discipline. This chapter does not provide an exhaustive literature review, but rather highlights studies which illustrate the potential of macrofossil analysis and, in turn, some of the challenges and future possibilities associated with the technique. This review focuses on Holocene estuarine systems as they provide the most relevant context for understanding the current status of estuarine aquatic plants.

\section{Relative Sea-level Change}

The changing abundance of estuarine aquatic plants has long been used to document past changes in relative sea-level (Behre 1986). Furthermore, the obligate requirement of many aquatic plants for water provides a useful contrast to (some) faunal indicators (such as oysters and barnacles) which, due to the effect of tide, wave and wind splash, frequently live well above mean sea-level (Baker and Haworth 2000). 
The possibility of using single species indicators of sea-level change is highlighted by a study of the Spencer Gulf and Gulf St. Vincent, large inverse estuaries in South Australia. Belperio et al. (2002) used the presence of the seagrass Posidonia australis, which grows at depths of between 0.25-10 m below sea-level, as one of a range of (minimum) sea-level indicators. This extensive study, which encompassed more than 200 individual samples selected from over 500 cores, highlights the value of plant presence data for reconstructing relative sea-level changes. Belperio et al. (2002) demonstrated that the local sea-level high stand occurred 6400 calibrated years before present (cal. yr BP), with a steady decline from this time.

As part of a series of Holocene-scale paleogeography studies, Bennike et al. (2004) used plant macrofossils to determine relative shore level changes from cores collected in the Great Belt (Denmark). The Great Belt is part of a series of straits that connect the Kattegat with the Baltic Sea. The late-glacial and Holocene shore-level history of this region is governed by complex interactions between eustatic sea-level rise, isostatic rebound as a result of crustal 'unloading' following the melting and calving of the Fennoscandian ice sheet and damming by ice barriers in south-central Sweden. During the Younger Dryas Chronozone (YDC) shallow freshwater environments were inferred in the Great Belt from a plant assemblage including

Menyanthes trifoliata, Sparganium minimum, Potamogeton natans, $P$. praelongus, $P$. filiformis and Zannichellia palustris. The presence of $P$. natans, $P$. praelongus and $Z$. palustris was argued to indicate that mean temperatures in the warmest month during the YDC were not below $10^{\circ} \mathrm{C}$. Later, in the early Holocene $(c$. 10,100 cal. yr BP), lake shore deposits were identified through the presence of abundant remains of fringing Phragmites australis. Following this, an increasingly large lake was inferred from charophyte remains (oospores) and, to a lesser extent, seeds and fruits from Najas minor, N. marina, N. flexilis and Z. palustris up to approximately $8,800 \mathrm{cal}$. yr BP. The presence of $N$. minor, which presently occurs at a latitude no higher than northern Germany, was taken to suggest that summer temperatures were warmer in the early Holocene than at present. Freshwater plants were not present in sediments deposited after 8800 cal. yr BP signalling the time when brackish-water environments were established because the eustatic sea-level rise likely surpassed local glacio-isostatic rebound. Notably, marine environments after 8100 cal. yr BP were inferred from the aquatic fauna (with little evidence provided by plants), highlighting the value of multiple indicators in studies of this type.

A number of studies have used macrofossils (often in conjunction with pollen, foraminifera, ostracods and diatoms) to infer shifts between freshwater and saltmarsh environments and, hence, changing sea-levels. For example, Clark and Patterson (1985) undertook a detailed study of tidal influences at two sites (Fresh Marsh Pond and Deep Pond) over the last 1000 years on Long Island, New York State, USA. They concluded that, with good dating control, pollen and macrofossil records can readily record short-term changes in sea-level and associated plant communities. Similarly, Freund et al. (2004) used remains of a number of aquatic plants, in combination with pollen, diatoms and foraminifera, to identify estuarine environments of varying elevations (e.g. lagoons, "low" and "high" salt marsh) in refining estimates of late Holocene sea-level variation on the German North Sea coast. This study permitted the development of a precise relative sea-level curve in which lowering of approximately $40 \mathrm{~cm}$ was postulated during the Little Ice Age (Freund et al. 2004). 
Donnelly and Bertness (2001) used plant macrofossils in New England (USA) saltmarshes to document recent changes in sea-level. The cordgrass Spartina alterniflora inhabits the frequently flooded lower elevations of New England saltmarshes, relative to high marsh species such as Spartina patens (marsh hay). Donnelly and Bertness (2001) showed that an unprecedented shift to cordgrassdominance (in a 2500 year history of the region) from the mid- $19^{\text {th }}$ century was very strongly matched to the magnitude and rate of sea-level rise recorded from regional tide gauge records. With predicted future sea-level rises due to climate change, Donnelly and Bertness (2001) predict a drowning of cordgrass-dominated communities during the next century resulting in extensive saltmarsh losses.

Macrofossils have been used to document the isolation of lakes from the sea after the last deglaciation. Numerous low elevation lakes in formerly glaciated regions have been isolated from the sea because the isostatic rebound has surpassed sea-level rise. Distinct peaks of aquatic plants such as charophytes, Potamogeton spp., Myriophyllum spp. and Callitriche spp. can be seen in sediments deposited just after lakes were isolated (Bennike 1995; Bennike et al. 2011; Sparrenbom et al. 2013). Such basins go through a brackish-water phase during isolation with the duration of this phase dependent on the rate of sea-level rise.

\section{Human Impact, with a Focus on Changes in Salinity}

Estuaries have long been severely affected by human activities, because they are located at the downstream end of river catchments and because they are focal points for human settlement (Agardy et al. 2005). Several studies have used macrofossils to identify human impacts on estuarine ecosystems (e.g. Brush and Davis 1984; Sritrairat et al. 2012). The most comprehensive plant macrofossil study in coastal systems was undertaken as part of the CASSARINA project that investigated rates and causes of ecological change in several North African lakes (Flower 2001; Birks et al. 2001a). In this study, plant macrofossil histories were constructed for nine North African lakes, seven of which (three in Egypt, two in Tunisia and two in Morocco) were influenced by their connection to the ocean.

In the Moroccan lake, Sidi Bou Raba, the plant macrofossil history suggested a shift from a clear water lake (supporting charophytes, Potamogeton spp., Najas armata and Ruppia spp.) before the 1860 s to a turbid and increasingly shallow system thereafter, with recent (post-1985) colonisation of saline exposed muds by Salicornia europaea. In another Moroccan site, Merga Zerga, increases of salinity and nutrient inputs were inferred. The Merga Zerga record was short, dating to $c .1950$, but still showed recent declines of Ruppia spp., charophyte beds, along with Potamogeton spp. and the seagrass Zostera spp. (in the mid-1980s; Birks et al. 2001b).

Lake Ichkeul, a World Heritage site in Tunisia due to its significant avifauna (IUCN 2010), (has undergone substantial ecological change (Birks et al. 2001b). Interestingly, many critical aspects of the site's hydrology are due to human intervention. The construction of the Bizerte Ship Canal in 1895 increased the ingress of sea-water and, as a consequence, Potamogeton and Ruppia communities were established for the first time. The maximum expansion of these submerged plants was dated to between $c .1950$ and 1975. In the 1980s, diversion of inflowing rivers resulted in increased salinity in the lake and a marked reduction of Potamogeton and Ruppia stands. Tragically, the 1980 inclusion of Lake Ichkeul on the World Heritage List largely coincided with a decline in ecosystem health from which it has never recovered. 
Lakes in the Nile delta (Edku, Burullus, Manzala) have suffered from freshening as a result of elevated irrigation discharges from the regulated Nile River. Although this practice commenced in the early $20^{\text {th }}$ century, it was dramatically accentuated with the completion of the Aswan High Dam in 1964. In the highest resolution CASSARINA macrofossil record, that from Edku Lake (Figure 1), increases in freshwater submerged (Potamogeton pectinatus), free-floating (Lemna minor) and emergent (Typha spp.) aquatic macrophytes occurred after 1965 (Birks et al. 2001b). In Burrullus Lake, the most marked changes were increases in Typha and Ruppia from the 1940s and more recent increases in P. pectinatus. In Manzala Lake, a number of submerged taxa, including Ruppia, Chara, Potamogeton and Ceratophyllum, became more abundant after $c .1945$.

Mirroring the observations at Lake Ichkeul (Tunisia), Dick et al. (2011) showed that key aspects of the ecology of The Coorong, a Ramsar-listed coastal lagoon in South Australia, may be due to human intervention. In The Coorong, salinity increases with distance from the ocean (to many times that of sea water). Marked alterations to the ecosystem have been documented using plant and other fossil remains (Figure 2). The salinity tolerant aquatic macrophyte Ruppia tuberosa was, at least for the core site investigated, shown to be a post-European settlement arrival and only expanded in or after the 1950s. This finding is significant since this plant is used by globally significant populations of migratory birds that overwinter in The Coorong from the Palearctic (Paton et al. 2009). Dick et al. (2011) suggested, based on the salinity preferences of the aquatic plants themselves, but with corroboration by diatom and foraminifera data, that increases in salinity as a result of substantial upstream abstractions, resulted in the extirpation of Ruppia megacarpa (which has a lower salinity tolerance than $R$. tuberosa) from the south lagoon of The Coorong and a post-European settlement increase in Ruppia tuberosa. This conclusion contrasts with Paton et al. (2009) who argued that water level was the key driver of changes in food resources for birds. These differences in interpretation, though they operate on different timescales (decades versus centuries), serve to highlight "unknown unknowns" (sensu Rumsfeld 2002) in the palaeoenvironmental record, where only a limited number of possible environmental stressors can be reconstructed. In keeping with the observations of Birks et al. (2001b), Dick et al. (2011) suggested that evaluation of the spatial extent of changes, through the analysis of additional sediment records, may help to resolve some of these questions.

\section{Informing Nature Conservation}

The ability to reconstruct former estuarine plant communities and, in turn, past tidal influences and environmental conditions, is especially valuable to the development of conservation and restoration strategies in estuaries. In conjunction with other sediment proxies, plant macro-remains can be used to infer the range of former conditions (salinity, sea-level) and plant communities that existed prior to major human influence. Equally, in some cases, plant macro-remains can be used to inform on the conservation of rare coastal plants.

In a floodplain mire in the Norfolk Broads wetland, UK, Wells and Wheeler (1999) successfully used macrofossils and foraminifera to identify a series of vegetation changes over the last two millennia. From 2000-1600 cal. yr BP, an upper saltmarsh system prevailed due to a period of marine transgression. This estuarine phase was rapidly replaced after $1600 \mathrm{cal}$. yr BP by freshwater fen and swamp communities that have persisted in various forms to the present-day. With recent 
climate change, and increasing threats to freshwater nature reserves (including the Norfolk Broads system) from saline incursions and sea floods, information on the former extent and nature of coastal environments is of considerable value to conservation decision-making, especially with respect to "defend or retreat" debates.

The potential for using palaeoecological analyses to establish benchmarks to assist the development of estuarine conservation and restoration strategies was demonstrated by Desroches et al. (2013) for the St. Lawrence River estuary, Canada. In this estuary there are around 2130 hectares of cordgrass-dominated (Spartina spp.) saltmarsh, much of which has been affected by agricultural encroachment over the last 150 years. According to local experts, it was argued that one remaining saltmarsh patch (Pointe-aux-Épinettes) might act as a contemporary ecological benchmark to help inform conservation activities. To test this hypothesis, an extensive (349 point) survey of the extant vegetation was undertaken in the Pointe-aux-Épinettes saltmarsh, in combination with macrofossil analysis of three spatially separated sediment cores. The macrofossil analysis suggested considerable dynamism of plant communities over recent centuries in all three cores, with short-term changes in dominance of many plants (including Salicornia maritima, Spartina patens, Puccinellia cf. tenella, Plantago maritima, Glaux maritima) related to small disturbances. Nevertheless, few fundamental species replacements were evident during the last 160 years - a period of major potential human-disturbance. Furthermore, current plant assembly in the saltmarsh exhibited high overlap with recent assemblages in the cores (which included a high proportion of native taxa) suggesting that the proposed benchmark site was broadly representative of an undisturbed saltmarsh and, thus, suitable for informing local conservation activities.

A further conservation application of macrofossil analysis in estuarine ecosystems lies with determining the history of, and potential threats to, rare coastal plants. For example, Birks (2002) documented the stepped extirpation of the floating fern Azolla nilotica from Egyptian lakes, with the latest and final decline occurring in the 1960s from Burullus Lake. This plant is now extinct in Egypt and its extinction was thought to be linked to a freshening of wetlands and/or eutrophication due to fertiliser enriched inflow (Birks 2002). In a study focused on the rare brackish water charophyte, Lamprothamnium papulosum, in The Fleet Lagoon, south-west England, Carvalho et al. (2000) used a combination of charophyte oospores and diatom analyses to relate long-term changes in L. papulosum oospore abundance to long-term changes in tidal influence and salinity inferred from diatoms (Figure 3). Redundancy analysis showed that salinity (inferred from diatoms) explained $34 \%$ of the variation in oospore numbers, with higher oospore numbers generally associated with freshbrackish conditions. The study suggested that L. papulosum performance was improved when marine influence was reduced in the lagoon.

\section{Methodological considerations and future prospects}

While it is possible, due to changes in relative sea-level, for plant macrofossil studies of estuaries to examine exposed sediments (e.g. Freund et al. 2004), the majority of studies are conducted using sediment cores. Site selection and sediment coring techniques are discussed elsewhere (Skilbeck et al., this volume), but considerations pertinent to plant macrofossil analysis are discussed here. A key issue for macrofossil studies, as for all palaeoecological inferences, is the extent to which fossils reliably represent former plant communities. Much is known in this respect for freshwater lakes, where a high proportion of submerged and floating-leaved aquatic macrophytes 
leave identifiable remains in cores. Furthermore, a number of studies in freshwater environments have shown the deposition of plant macrofossils to be highly localised (Birks 1973; Birks 2001; Clarke et al. 2014). It follows that, where aquatic vegetation is patchy and representation of water body-scale changes and species diversity is important, a multiple coring location approach is most appropriate (e.g. Madgwick et al. 2011). Nevertheless, single cores can provide an excellent summary of the dominant vegetation changes in small water bodies (Davidson et al. 2005; Sayer et al. 2010), indicating that strong temporal change often out-weighs issues of spatial variability.

Given the dynamism of tidal environments, it might be expected that macrofossil representation of coastal plants would be especially problematic and difficult to predict, with non-local plant remains incorporated into sediment assemblages due to long-distance water dispersal. Indeed, in one early study of river banks in a Welsh estuary (Milton, 1939), the seed bank did not correspond well with the surface vegetation. Equally, in a study of strand line deposits along the tidal River Rhine and the North Sea coast of The Netherlands, Cappers (1993) found macrofossil remains (diaspores and vegetative fragments) from a remarkable 351 taxa, many of which were derived from distant source communities and, in some cases, different geological periods: Carboniferous fossils were found. Thus, careful interpretation of sub-fossil assemblages was recommended. By contrast, other research in coastal marshes has shown a good relationship between seed assemblages and standing vegetation. For example, in San Francisco Bay, California, Goman (2001) examined 53 sampling stations covering saline, brackish and freshwater plant communities and found a strong association between both plant communities and macro-remains such that different salinity environments could easily be distinguished by both (Figure 4). In turn, this suggested that macrofossils might be usefully employed to reconstruct palaeo-salinity and the changing geographical configuration of coastal habitats. It is clear that plant-fossil relationships in estuarine environments may vary considerably depending on hydrological context e.g. quiescent and weakly tidal lagoons vs. strongly tidal rivers and marshes.

A key challenge for macrofossil studies lies in the interpretation of fossil remains in terms of changing plant abundances and coverage. Due to the varying production and preservation of macro-remains derived from different species, there is always a tendency for both over and under-representation. For example, charophytes can produce huge quantities of fossil oospores, even though actual plant abundances may be low (Zhao et al. 2006; Clarke et al. 2014). Equally, Salicornia species in saltmarshes can produce large numbers of remains relative to their actual representation (Hopkins and Parker, 1984). Alternatively, for seagrasses, vegetative reproduction typically dominates (Waycott et al. 2006) and, consequently, seeds may be relatively rare (Inglis 1999). Given these issues, Goman (2001) quite rightly argued that taphonomic studies ought to be routinely incorporated into palaeoenvironmental investigations and, to varying degrees, this has been the case.

Birks (2014) discusses the representation and analysis of plant macrofossil data, emphasising the need for appropriate scaling of taxa with greatly varying abundance. One way of improving palaeo-interpretations and partially factoring out some of the bias associated with species overrepresentation is to express fossil data on abundance scales (as opposed to concentrations as is typical) that reflect the varying production of different plant fossils. This approach was used by Odgaard and Rasmussen (2001) for a set of seven shallow Danish lakes. In this study, frequencies of plant remains from all core samples ( $\mathrm{n}=190,167$ of which contained macrofossils) 
were standardised against the maximum abundance of each fossil. Concentrations of fossils in all samples could then be transformed into a 4-level frequency scale (abundant, common, rare, absent). Despite the ingenuity of this approach, which partly accounts for the differential production/preservation of remains from different plants, it has rarely been used to help interpret core sequences. Clearly, sufficient regional data must exist for both coastal and freshwater plant macrofossils to make for even more robust and useful abundance calibrations in the future (Birks 2014).

Enhanced ecological interpretations in coastal environments, especially in lakes and lagoons, will likely emerge from an improved ability to identify oospores from Characeae. Charophyte oospores are abundantly produced and, where the ecology of species is well understood, they are excellent indicators (García, 1994; García, 1999). However, the identification of oospores and gyrogonites (the calcified coating of oospores) to species-level presents severe challenges to all but highly specialised experts and available keys are notoriously incomplete and hard to use. To better harness information about oospores from charophytes, it might be possible to use genetic approaches, or possibly oospore germination (e.g. Rodrigo et al. 2010), since oospores are known to be especially long-lived in "seedbanks" (Beltman and Allegrini, 1997). The huge potential of oospore remains is clearly demonstrated by Rodrigo et al. (2010) in a palaeolimological study of Albufera de Valéncia, a Spanish coastal lagoon. Some ten charophyte species were successfully identified (from keys and from comparisons with reference material) from oospores and used to track an early period of freshening and a later (post-1900) phase of eutrophication which eventually led to the extirpation of charophyte beds from the site. In a study of Bombah Broadwater, a shallow coastal lake on the New South Wales coast, Australia, Leyden et al. (2011) recorded seven charophyte taxa from oospores. In combination with animal macrofossils, the charophyte record suggested that vegetation changes after European arrival (c. 1850) led to increased catchment run-off, resulting in a freshening of the site. In particular, increased abundances of the freshwater charophytes Chara globularis, C. fibrosa and Nitella hyalina were used to identify recent declines in salinity.

An additional challenge for macrofossil research in coastal environments, as in freshwaters, stems from sample size limitations. To best represent some sparsely produced plant remains, ideally large sediment volumes are needed. This need was recognised long ago by Birks et al. (1976) who used a $15 \mathrm{~cm}$ diameter core in their study of Lake Sallie. In open water regions (e.g. lagoons, coastal lakes, estuarine bays) commonly used corers (e.g. Livingstone, Glew, Mackereth and other corers) only collect relatively modest volumes $\left(<30 \mathrm{~cm}^{3}\right)$ of sediment per $1 \mathrm{~cm}$ slice (Glew et al. 2001). To this end, the recently developed wide-bore (14 cm internal diameter) Big Ben piston corer (see Patmore et al. 2014), which allows c. $150 \mathrm{~cm}^{3}$ of sediment to be collected in a single $1 \mathrm{~cm}$ interval, might be usefully employed in estuarine settings.

\section{Conclusions}

Estuarine plants provide enormous benefit to humans and numerous other species. However, despite adaptation to short-term environmental variability, estuarine vegetation is highly vulnerable to a multitude of human-induced threats including habitat change, sea-level rise, aquaculture, point and diffuse point pollution and river regulation (Short et al. 2011). Palaeoenvironmental approaches can document the full extent of changes which have already occurred in these systems. Additionally, they can document past natural rates of change (e.g. due to species succession, estuarine 
infilling and climate variation) which can be contrasted to rates of anthropogenic modification and help refine estimates of future change (e.g. climate-driven range shifts). Where ecosystems have not been markedly degraded (e.g. Desroches et al. 2013), macrofossil analysis can help identify priority locations for nature reserves.

Many studies of plant remains in coastal waterbodies demonstrate that there was fundamental, "early" post-industrial revolution change which would be invisible in the absence of palaeolimnological studies and that, furthermore, many estuaries have continued to be degraded in more recent times. Interestingly, for some ecosystems with high conservation value (i.e. Lake Ichkeul, Tunisia and The Coorong, South Australia) the environmental conditions leading to this status are, at least partly, the result of human modification. However, at both these sites ongoing human interference has resulted in continued ecological degradation.

The studies cited in this chapter have shown that it is possible to document local extinctions of species through both natural (e.g. N. minor in the Danish Great Belt) and human agency (e.g. Azolla nilotica in the Nile Delta lakes and $R$. megacarpa in The Coorong, South Australia). Documented local plant extinction is among the most important contribution that studies of plant macro remains have made to understanding the history of estuaries and coastal lakes. Since the nature of plant communities fundamentally affects ecosystem function (Dibble and Meyerson 2014), and restoration programmes focus on re-establishing pre-impact plant communities (Watson et al. 2011), plant macrofossil analysis can provide information critical to ecosystem rehabilitation. In conclusion, while this chapter has focussed specifically on studies of macroscopical plant remains, it is clear that studying such remains in combination with other indicators (such as diatoms and animal remains) allow us to better understand both waterbody changes and the drivers of those changes (e.g. such as shifts in salinity, Birks et al. 2001b; Dick et al. 2011; Leyden et al. 2011). 


\section{References}

Adam P (2012) Introduction. In: Sainty GR, Hosking J, Carr G, Adam P (Eds). Estuary plants and what's happening to them in south-east Australia. Sainty and Associates, Potts Point NSW, Australia, pp. 4-35.

Agardy T, Alder J, Dayton P, Curran S, Kitchingman A, Wilson M, Catenazzi A, Restrepo A, Birkeland C, Blaber S, Saifullah S, Branch G, Boersma D, Nixon S, Dugan P, Davidson N, Vörösmarty C (2005) Coastal Systems. In: Hassan R, Scholes R, and Ash N (Eds.), Ecosystems and human well-being: current state and trends: findings of the condition and trends working group. Island Press, Washington, p. 513549

Alongi DM (2008) Mangrove forests: Resilience, protection from tsunamis and responses to global climate change. Est Coast Shelf Sci 76:1-13

Appleby PG, Birks HH, Flower RJ, Rose N, Peglar SM, Ramdani M, Kraïem MM, and Fathi AA (2001) Radiometrically determined dates and sedimentation rates for recent sediments in nine North African wetland lakes (the CASSARINA project). Aquat Ecol 35:347-67

Beltman B, Allegrini C (1997). Restoration of lost aquatic plant communities: new habitats for Chara. Neth J Aquat Ecol 30:331-337

Baker RGV, Haworth RJ (2000) Smooth or oscillating late Holocene sea-level curve? Evidence from cross-regional statistical regressions of fixed biological indicators. Mar Geol 163:353-365

Behre KE (1986) Analysis of botanical macro-remains. In: Plassche O (Ed.), SeaLevel Research. Springer Netherlands, p. 413-433

Belperio AP, Harvey N, Bourman RP (2002) Spatial and temporal variability in the Holocene sea-level record of the South Australian coastline. Sed Geol 150 (1-2):153169

Bennike O (1995) Palaeoecology of two lake basins from Disko, West Greenland. J Quat Sci 10:149-55

Bennike O, Jensen, JB, Lemke W (2001) Late Quaternary records of Najas spp. (Najadaceae) from the southwestern Baltic region. Rev Palaeobot Palynology 114:259-267

Bennike O, Jensen, JB, Lemke W, Kuijpers A., Lomholt S (2004) Late- and postglacial history of the Great Belt, Denmark. Boreas 33:18-33.

Bennike O, Wagner B, Richter A (2011) Relative sea level changes during the Holocene in the Sisimiut area, south-western Greenland. J Quat Sci 26:353-61

Birks HH (1973) Modern macrofossil assemblages in lake sediments in Minnesota. In: Birks HJB, West RG (Eds.), Quaternary Plant Ecology. Blackwell, Oxford. p. 173-190

Birks HH (2001) Plant macrofossils. In: Smol JP, Birks HJB, Last WM (Eds.), Tracking environmental change using lake sediments. Volume 3: terrestrial, algal and siliceous indicators. Kluwer Academic Publishers, Dordrecht, The Netherlands. P. 49-74 
Birks HH, Whiteside MC, Stark DM, Bright RC (1976) Recent paleolimnology of three lakes in Northwestern Minnesota. Quat Res 6:249-72

Birks HH, Birks HJB, Flower RJ, Peglar SM, Ramdani M (2001a) Recent ecosystem dynamics in nine North African lakes in the CASSARINA project. Aquat Ecol 35:467-478

Birks HH, Peglar S, Boomer I, Flower RJ, Ramdani M, Appleby PG with contributions from Appleby, PG, Bjune, AE, Patrick, ST, Kraïem, MM, Fathi, AA, Abdelzaher, HMA (2001b) Palaeolimnological responses of nine North African lakes in the CASSARINA Project to recent environmental changes and human impact detected by plant macrofossil, pollen, and faunal analyses. Aquat Ecol 35:405-30

Birks HH (2002) The recent extinction of Azolla nilotica in the Nile Delta, Egypt. Acta Palaeobotanica 42:203-213

Birks HJ (2014) Challenges in the presentation and analysis of plant-macrofossil stratigraphical data. Vegetation History and Archaeobotany 23:309-30

Blindow I (2000) Distribution of Charophytes along the Swedish coast in relation to salinity and eutrophication. Internat. Rev. Hydrobiol. 85:707-717

Bradshaw EG, Rasmussen P, Nielsen H, Anderson NJ (2005) Mid- to late-Holocene land-use change and lake development at Dallund Sø, Denmark: Trends in lake primary production as reflected by algal and macrophyte remains. Holocene 15:11301142

Bromberg Gedan KB, Silliman BR, Bertness MD (2009) Centuries of human-driven change in salt marsh ecosystems. Ann Rev Mar Sci 1:117-141

Brush GS, Davis FW (1984) Stratigraphic evidence of human disturbance in an estuary. Quat Res 22:91-108

Carvalho L, Bingham N, Martin A (2000) Lagoonal charophyte conservation: a palaeoecological approach. Proceedings of the International Association of Theoretical and Applied Limnology 27:884-886

Cappers, R.T.J. (1993) Seed dispersal by water: a contribution to the interpretation of seed assemblages. Veg Hist Archaeobotany 2:176-186

Clark JS, Patterson WA III (1985) The development of a tidal marsh: Upland and oceanic influences. Ecol Monographs 55:189-217

Clarke GH, Sayer CD, Turner S, Salgado J, Meis S, Patmore IR, Zhao Y. (2014) Spatial representation of aquatic vegetation change by plant macrofossils in a small and shallow freshwater lake. Veg Hist Archaeobotany 23:265-276

Davidson TA, Sayer CD, Bennion H, David C, Rose N, Wade MP (2005) A 250 year comparison of historical, macrofossil and pollen records of aquatic plants in a shallow lake. Fresh Biol 50:1671-1686

Desroches MB, Lavoie M, Lavoie C (2013) Establishing the value of a salt marsh as a potential benchmark: Vegetation surveys and paleoecological analyses as assessment tools. Botany 91:774-785

Dibble, KL,Meyerson, LA (2014) The Effects of Plant Invasion and Ecosystem Restoration on Energy Flow through Salt Marsh Food Webs. Estuar Coast 37:339353 
Dick J, Haynes D, Tibby J, Garcia A, Gell P (2011) A history of aquatic plants in the Coorong, a Ramsar-listed coastal wetland, South Australia. J Paleolimnol 46:623-635

Dieffenbacher-Krall AC, Nurse AM (2005) Late-glacial and Holocene record of lake levels of Mathews Pond and Whitehead Lake, Northern Maine, USA. J Paleolimnol 34:283-309

Donnelly JP, Bertness MD (2001) Rapid shoreward encroachment of salt marsh cordgrass in response to accelerated sea-level rise. PNAS 98:14218-23.

Duarte CM (1999) Seagrass ecology at the turn of the millennium: Challenges for the new century. Aquat Bot 65:7-20

Eyre BD, Maher DT, Squire P (2013) Quantity and quality of organic matter (detritus) drives $\mathrm{N}_{2}$ effluxes (net denitrification) across seasons, benthic habitats, and estuaries. Global Biogeochemical Cyc 27:1083-1095

Flower R.J. 2001. Change, Stress, Sustainability and Aquatic ecosystem Resilience In North African wetland lakes during the 20th century: an introduction to integrated biodiversity studies within the CASSARINA project. Aquat Ecol 35:261-302

Freund H, Gerdes G, Streif H, Dellwig O, Watermann F (2004) The indicative meaning of diatoms, pollen and botanical macro fossils for the reconstruction of palaeoenvironments and sea-level fluctuations along the coast of Lower Saxony; Germany. Quat Int 112:71-87

Garcia A 1994. Charophyta: their use in paleolimnology. J Paleolimnol 10:43-52

García, A. (1999) Charophyte flora of south-eastern south Australia and southwestern Victoria, Australia: Systematics, distribution and ecology. Aust J Bot 47:407426

Glew J, Smol JP, Last WM (2001) Sediment core collection and extrusion. In: Last WM, Smol JP (Eds.), Tracking Environmental Change using Lake Sediments, Volume 1, Basin Analysis, Coring, and Chronological Techniques. Kluwer Academic Publishers, Dordrecht, p. 73-105

Goman, M. (2001) Statistical analysis of modern seed assemblages from the San Francisco Bay: applications for the reconstruction of paleo-salinity and paleo-tidal inundation. J Paleolimnol, 24:393-409

Hopkins, D.R., Parker V.T. (1984) A study of the seedbank of a salt marsh in Northern San Francisco Bay. Am J Bot 71:348-355

Inglis GJ (1999) Variation in the recruitment behaviour of seagrass seeds: Implications for population dynamics and resource management. Pacific Cons Biol 5:251-9

International Union for the Conservation of Nature [IUCN] (2010) IUCN Red List of Threatened Species. www.iucnredlist.org (accessed 7/5/14)

Jenkins R (1955) The Cone Gatherers. Macdonald, London, 223p.

Leyden E, Tibby J, García A, Zawadzki A (2011) Unexpected post-settlement freshening and increase in charophytes in Bombah Broadwater (Myall Lakes, New South Wales, Australia). J Paleolimnol 46:637-647 
Madgwick,G. Emson D, Sayer CD, Willby NJ, Rose N, Jackson MJ, Kelly A (2011) Centennial-scale changes to the aquatic vegetation structure of a shallow eutrophic lake and implications for restoration. Fresh Biol 56:2620-2636.

Martin A, Carvalho L, Downie AJ (2002) Rare charophytes in Scotland's coastal saline lagoons. Bot J Scot 54:23-35

Milton WEJ (1939) The occurrence of buried viable seeds in solis at different elevations in a salt marsh. J Ecol 27:149-159

Mitsch WJ, Gosselink JG (2007) Wetlands 4th edn, John Wiley \& Sons, New York

Montefalcone M (2009) Ecosystem health assessment using the Mediterranean seagrass Posidonia oceanica: A review. Ecol Indic 9:595-604

Odgaard BV, Rasmussen P (2001) The occurrence of egg-cocoons of the leech Piscicola geometra (L.) in recent lake sediments and their relationship with remains of submerged macrophytes. Arch Hydrobiol 152:671-686

Orth RJ, Carruthers TJB, Dennison WC, Duarte CM, Fourqurean JW, Heck Jr KL, Hughes AR, Kendrick GA, Kenworthy WJ, Olyarnik S, Short FT, Waycott M, Williams SL (2006) A global crisis for seagrass ecosystems. BioScience 56:987-996

Patmore IR, Sayer CD, Goldsmith B, Davidson TA, Rawcliffe R, Salgado J (2014) Big Ben: a new wide bore piston corer for multi-proxy paleolimmology. J Paleolimnol 51, 79-86

Paton DC, Rogers DJ, Hill BM, Bailey CP, Ziembicki M (2009) Temporal changes to spatially-stratified waterbird communities of the Coorong, South Australia: implications for the management of heterogeneous wetlands. Animal Cons 12:408-417

Rodrigo MA, Alonso-Guillén JL, Soulié-Märsche I (2010) Reconstruction of the former charophyte community out of the fruitifications identified in Albufera de Valéncia lagoon sediments. Aquatic Bot 92:14-22

Rumsfeld D (2002) Department of Defense (USA) news briefing. www.defense.gov/transcripts/transcript.aspx?transcriptid=2636. Accessed on $20 / 12 / 13$

Sayer CD, Burgess A, Kari K, Peglar S, Davidson TA, Yang H, Rose N (2010) Long-term dynamics of submerged macrophytes and algae in a small and shallow, eutrophic lake: implications for the stability of macrophyte-dominance. Fresh Biol 55:565-583

Short FT, Polidoro B, Livingstone SR, Carpenter KE, Bandeira S, Bujang JS, Calumpong HP, Carruthers TJB, Coles RG, Dennison WC, Erftemeijer PLA, Fortes MD, Freeman AS, Jagtap TG, Kamal AHM, Kendrick GA, Judson Kenworthy W, La Nafie YA, Nasution IM, Orth RJ, Prathep A, Sanciangco JC, Tussenbroek BV, Vergara SG, Waycott M, Zieman JC (2011) Extinction risk assessment of the world's seagrass species. Biol Conserv 144:1961-1971

Short FT, Wyllie-Eciieverria S (1996) Natural and human-induced disturbance of seagrasses. Env Cons 23:17-27

Sparrenbom CJ, Bennike O, Fredh D, Randsalu-Wendrup L, Zwartz D, Ljung K, Björck S, Lambeck K (2013) Holocene relative sea-level changes in the inner Bredefjord area, southern Greenland. Quat Sci Rev 69:107-24 
Sritrairat S, Peteet DM, Kenna TC, Sambrotto R, Kurdyla D, Guilderson T (2012) A history of vegetation, sediment and nutrient dynamics at Tivoli North Bay, Hudson Estuary, New York. Est Coast Shelf Sci 102-103:24-35

Torn K, Martin G, Kotta J, Kupp M (2010) Effects of different types of mechanical disturbances on a charophyte dominated macrophyte community. Est Coast Shelf Sci 87:27-32

Watson EB, Wasson K, Pasternack GB, Woolfolk A, Van Dyke E, Gray AB, Pakenham A, Wheatcroft RA (2011) Applications from Paleoecology to Environmental Management and Restoration in a Dynamic Coastal Environment. Rest Ecol 19:765-775

Waycott M, Procaccini G, Les DH, Reusch TBH (2006) Seagrass evolution, ecology and conservation: a genetic perspective. In: Larkum AWD, Orth RJ, Duarte CM (Eds.), Seagrasses: biology, ecology and conservation. The Netherlands, Dordrecht, The Netherlands, p. 25-50

Waycott M, Duarte CM, Carruthers TJB, Orth RJ, Dennison WC, Olyarnik S, Calladine A, Fourqurean JW, Heck KL, Hughes AR, Kendrick GA, Kenworthy WJ, Short FT, Williams SL (2009) Accelerating loss of seagrasses across the globe threatens coastal ecosystems. PNAS 106:12377-12381

Wells CE, Wheeler BD (1999) Evidence for possible climatic forcing of lateHolocene vegetation changes in Norfolk Broadland floodplain mires, UK. Holocene 9:595-608

Zhao Y, Sayer CD, Birks HH, Peglar SM. Hughes M (2006) Spatial representation of aquatic vegetation by macrofossil and pollen remains in a small and shallow lake. $\mathrm{J}$ Paleolimnol 35:335-350 


\section{Figure captions}

Fig. 1 Summary of plant and animal macrofossils from Edku Lake, Nile Delta, Egypt. Ages were estimated from ${ }^{137} \mathrm{Cs}$ and key events in the pollen and macrofossil records (Appleby et al. 2001). Modified from Birks et al. (2001b).

Fig. 2 Summary of plant and animal macrofossils from Villa dei Yumpa in the southern lagoon of The Coorong, South Australia, a currently hypersaline backbarrier lagoon. "o" and "g" in parentheses refer, respectively, to oospores and gyrogonites. Pinus is an introduced species in Australia and its presence indicates that sediments at and above this level were deposited after European settlement (c. post-1850).

Radiocarbon ages are listed with their associated errors. Material that was dated includes mollusc shells and Ruppia sp. fruits. Uncalibrated ages are shown due to problems associated with determining a precise marine reservoir age (Dick et al. 2011).

Fig. 3 Charophyte oospores (per $12 \mathrm{~cm}^{3}$ wet sediment) and diatom relative abundances in different salinity categories from a sediment core from Fleet Lagoon, Dorset, south-west England. Zones are derived from changes in the diatom assemblage. The increased abundance of Lamprothamnium papulosum oospores is associated with a freshening of the site (Carvalho et al. 2000).

Fig. 4 Discriminant function analysis scores for modern vegetation communities (a.) and plant remains (b.) with different salinity regimes in San Francisco Bay, California (Goman 2001). There is clear differentiation of both contemporary plants and fossil remains in relation to the salinity regime, with a particularly marked separation between fresh and saltwater sites. 


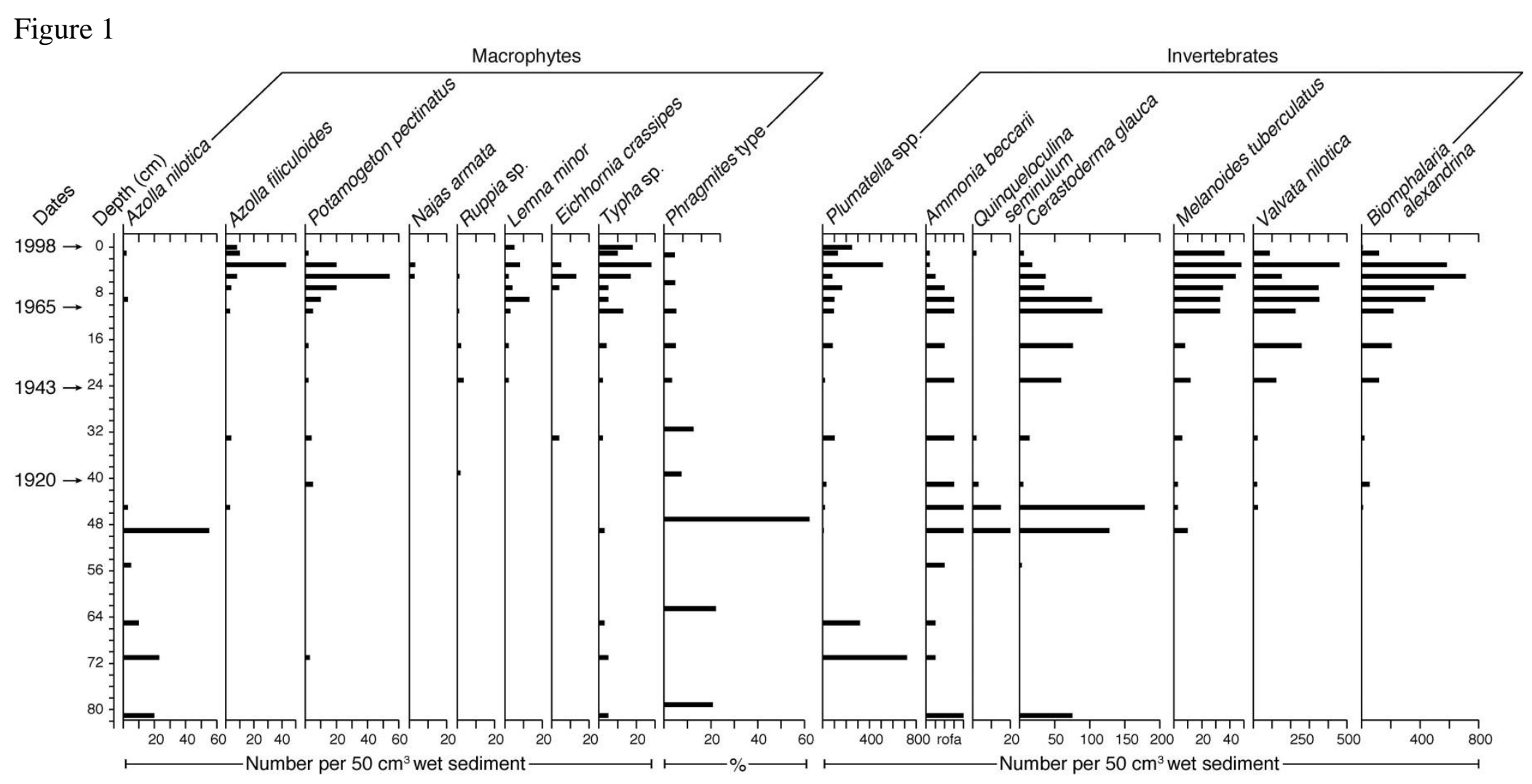


Figure 2

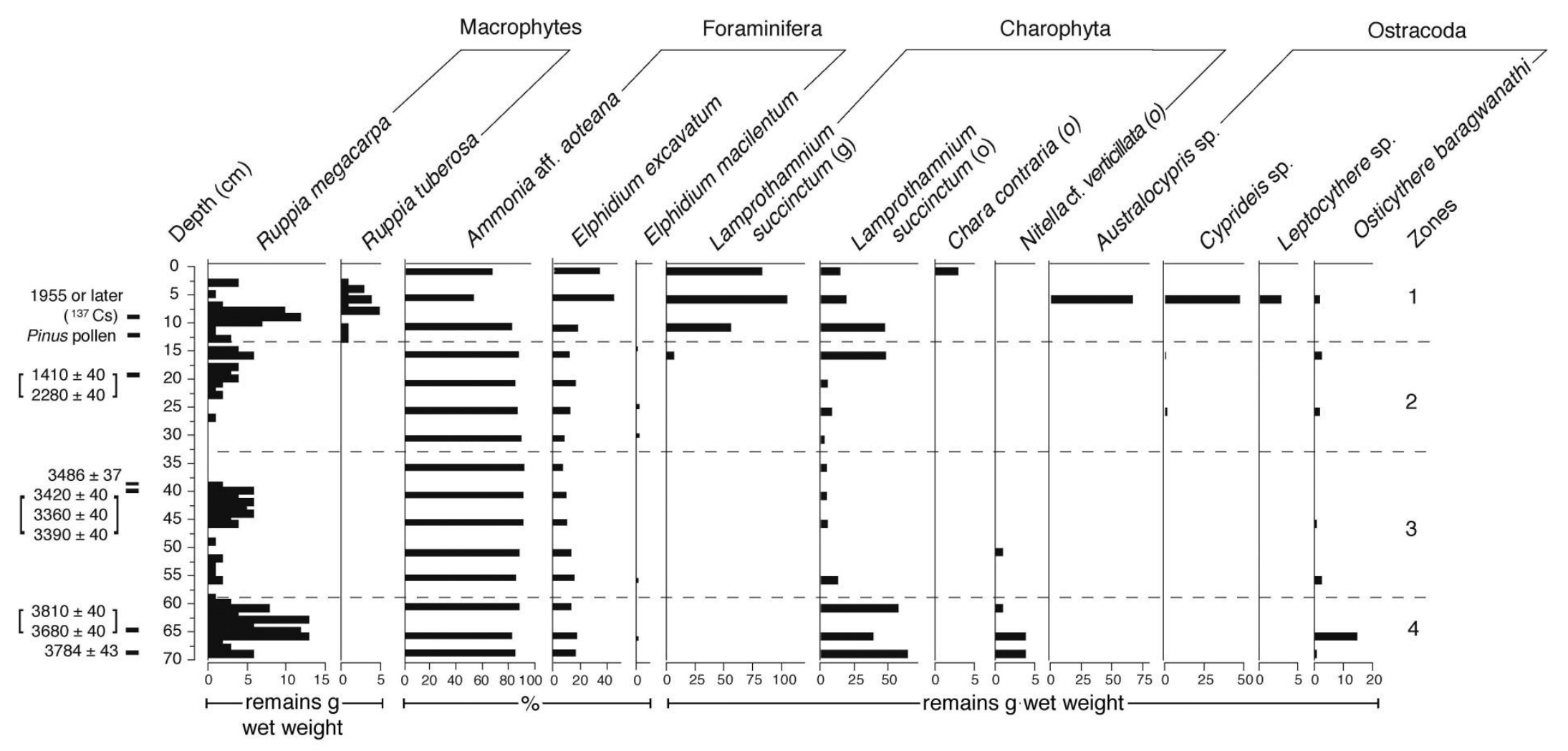

Figure 3 


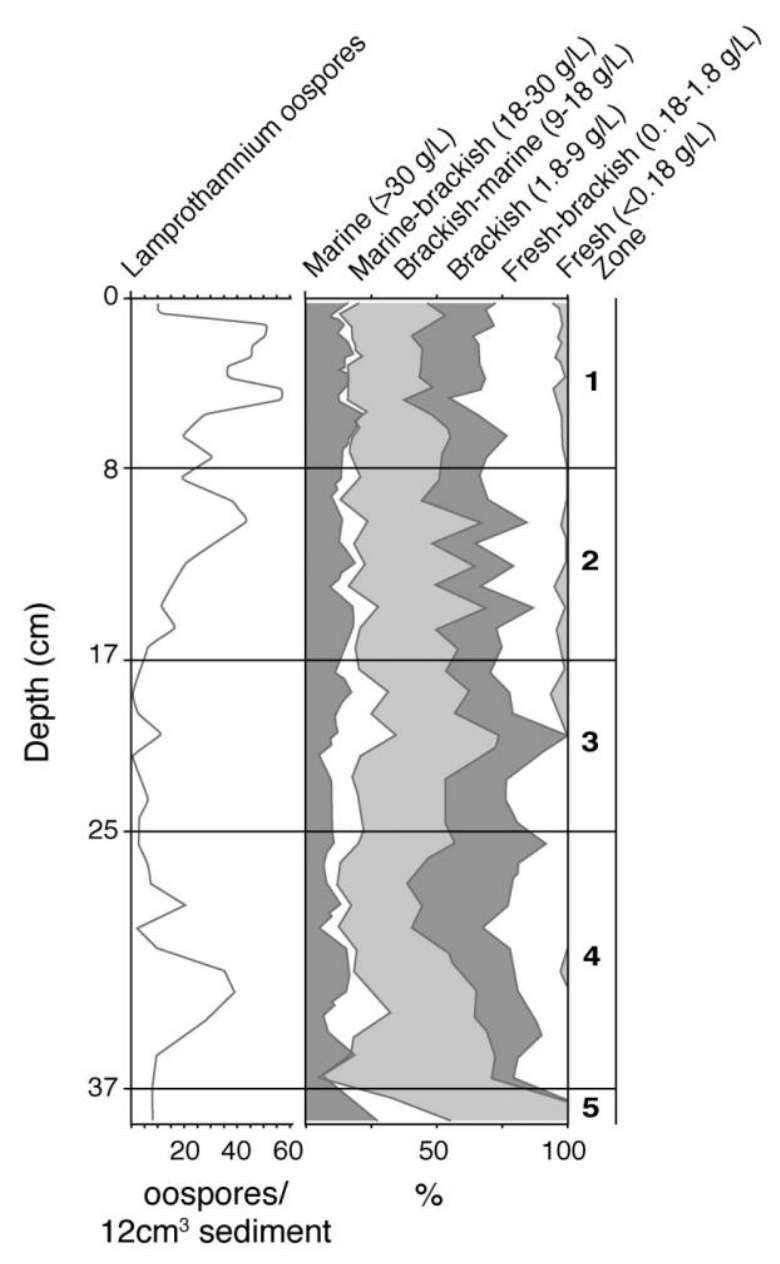


Figure 4

a.

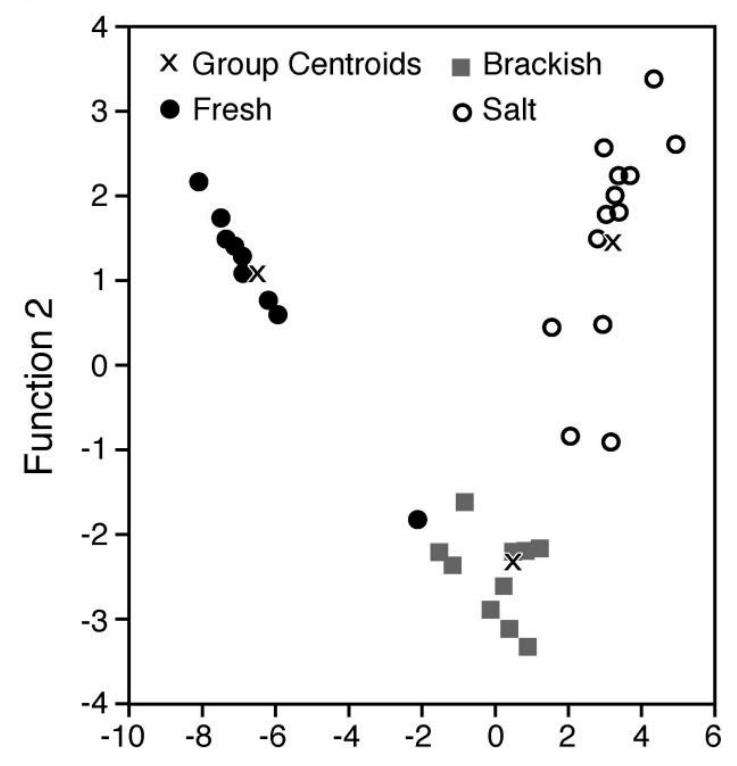

b.

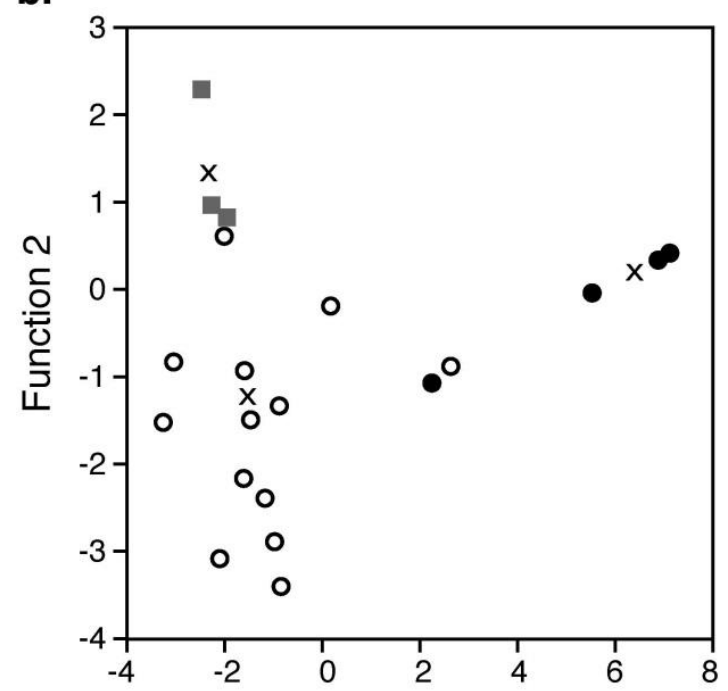

Function 1 